
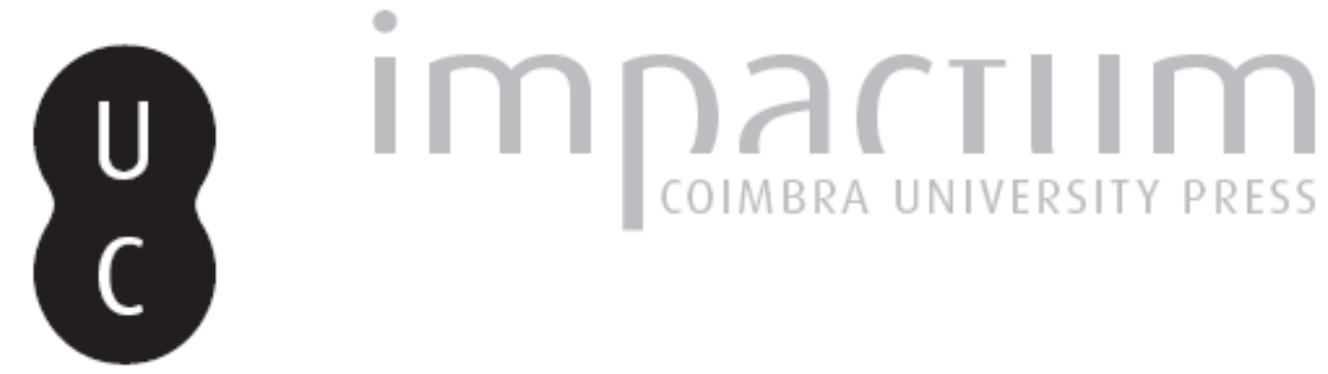

\title{
[Recensão a] FRANCISCO BETHENCOURT (2014). Racisms: From the Crusades to the Twentieth Century
}

Autor(es): $\quad$ Cassata, Francesco

Publicado por: Imprensa da Universidade de Coimbra

URL persistente:

URl:http://hdl.handle.net/10316.2/37842

DOI:

DOI:http://dx.doi.org/10.14195/0870-4112_3-1_17

Accessed : $\quad$ 26-Apr-2023 15:50:33

A navegação consulta e descarregamento dos títulos inseridos nas Bibliotecas Digitais UC Digitalis, UC Pombalina e UC Impactum, pressupõem a aceitação plena e sem reservas dos Termos e Condições de Uso destas Bibliotecas Digitais, disponíveis em https://digitalis.uc.pt/pt-pt/termos.

Conforme exposto nos referidos Termos e Condições de Uso, o descarregamento de títulos de acesso restrito requer uma licença válida de autorização devendo o utilizador aceder ao(s) documento(s) a partir de um endereço de IP da instituição detentora da supramencionada licença.

Ao utilizador é apenas permitido o descarregamento para uso pessoal, pelo que o emprego do(s) título(s) descarregado(s) para outro fim, designadamente comercial, carece de autorização do respetivo autor ou editor da obra.

Na medida em que todas as obras da UC Digitalis se encontram protegidas pelo Código do Direito de Autor e Direitos Conexos e demais legislação aplicável, toda a cópia, parcial ou total, deste documento, nos casos em que é legalmente admitida, deverá conter ou fazer-se acompanhar por este aviso.

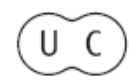






Revista da Faculdade de Letras da Universidade de Coimbra

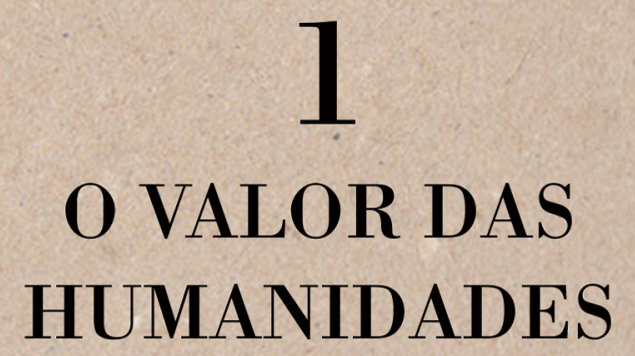

NÚMERO 1, 2015

3. ${ }^{\text {a }}$ SERIE 
FRANCISCO BETHENCOURT (2014).

\section{Racisms: From the Crusades to the Twentieth Century.}

Princeton: Princeton University Press, 464 pp.

As historian Frank Dikötter argued in 2011, it may seem trivial to underline that racism is a matter of politics, involving issues of power and prestige; the real question is to better specify the political dynamics of racism, despite a wide diversity of global examples. To pursue this fascinating task, Francisco Bethencourt, a leading historian of the Inquisition and Portuguese imperialism, has engaged himself in a complex and large overview of the history of racism - or, better, racisms - deftly combining institutional, social and cultural history approaches.

Bethencourt's analysis moves from a definition of racism based on two fundamental elements: first, prejudices concerning collective descent; second, the existence of a consistent and systematic discriminatory action. Following this broad conception of racism, the Charles Boxer Professor of History at King's College London traces the development of racism by covering an intimidating sweep of history, from classical antiquity to the $20^{\text {th }}$ century.

The first part of the book focuses on the Crusades and in particular on the process of displacement of people, increasing trade and redefinition of territories between Western Europe and Middle East, which accompanied them from the late $11^{\text {th }}$ to the late $13^{\text {th }}$ century. The Crusades - Bethencourt argues - contributed to renew religious and ethnic forms of identification, shaping classifications and hierarchies as well as negotiating the increasing tension between the universal aims of the Church and the Empire, on the one hand, and local policies on the ground, on the other. In this context, the discrimination against and segregation of Conversos and Moriscos after the Christian conquest

DOI • http://dx.doi.org/10.14195/0870-4112_3-1_17 
of Sicily and Iberia, rooted as it was on the notion of "purity of blood", can be considered the first "crucial case of racism», merging early prejudices concerning ethnic descent with institutionalized discriminatory action.

If this first part is centred around Jerusalem as symbolic site, the second one analyzes how the oceanic exploration in the mid- $15^{\text {th }}$ and $16^{\text {th }}$ centuries radically modified the European perception of the world, producing a permanent tension between the identification of an increasing varieties of peoples and the projection of stereotypical images onto African, American, and Asian populations. The third part discusses colonial societies from the $16^{\text {th }}$ through the $19^{\text {th }}$ centuries, describing different forms of ethnic classification; specific models of colonial practices in British, Dutch, French and Iberian America; local and transnational varieties of resistance against slavery and colonial racism.

By adopting the methodological tools of the history of ideas and history of science, the fourth part addresses the main characteristics of the theories of races from Carl Linnaeus to Houston Stewart Chamberlain along with their connection with social and political processes, namely in United States and Brazil. The final part of the book addresses the impact of nationalism in the elaboration and implementation of racial policies - from discrimination and segregation to genocide - in Europe, North and Latin America and Africa, during the $19^{\text {th }}$ and $20^{\text {th }}$ centuries.

In Racisms, Bethencourt consistently emphasizes a relational and interactive model of racism, stressing the polyphony and adaptability of racial discourses in different historical contexts. Far from being monolithic or fixed entities, racial belief systems are constructed by historical agents, and they are negotiated, appropriated and transformed within specific and complex cognitive, social and political situations. Even if the European expansion provides the main framework of Bethencourt's research in time and space, the global dimension is aptly considered in the very last chapters of the book, showing how racial categories and hierarchies were a significant aspect of intellectual and political discourse in China, Japan and India.

A second, distinctive feature of Bethencourt's reconstruction is represented by his emphasis on the centrality of aesthetics and visual stereotypes. In Racisms, iconographic reproductions are not mere illustrations in the conventional sense, 
though they complement the purpose of the narrative, by depicting the visual construction of racial myths and imaginaries, their continuities in the long term, and the constant interaction between visual and ideological discourses, on the one hand, and social and political practices, on the other: from this point of view, Bethencourt's reading of stereotypes, through the sarcophagi carved for Roger II of Sicily around 1140s, or Abraham Ortelius' atlas of the world - the Theatrum Orbis Terrarum (1570) - or again the casta paintings in $18^{\text {th }}$ century-Mexico - just to quote a few remarkable examples - is particularly original and significant. Unfortunately, despite the abundance and epistemological relevance of visual sources in the history of eugenics and scientific racism in the $19^{\text {th }}$ and $20^{\text {th }}$ centuries, the final part of the book seems to turn back to a more standardized modality of illustration, with classical photos of Nazi concentration camps and lynching in United States.

Finally, Bethencourt challenges unilateral interpretations of racism, while outlining the malleable and syncretic character of racial discourses, simultaneously based on cultural and natural elements. From this perspective, for instance, the case of the notion of "purity of blood", under the conditions of Christian Reconquest of Iberia, represents a telling example of a natural and cultural concept, which was instrumental for the implementation of a clear political project: denying converted Jews and Muslims access to public and ecclesiastical offices and excluding them from economic, social and political resources.

The historiography of racism is vast and increasingly differentiated. Quite understandably a four-hundred pages synthesis cannot but present some gaps. The analysis of the history of prejudice in classical antiquity, as well as the discussion concerning the transformation of racism in the post-WW2 period, receive just a cursory treatment in the economy of the book. Similarly, the ideological and political interaction between nationalism and racism, and the complex interplay between anti-Semitism and racism, would have certainly deserved lengthier and more-in-depth treatment.

That said, the book is well researched, introducing an impressive variety of the literature on the subject at hand, in addition to the author's own fieldwork. These elements make Racisms a must-read for scholars of Western racism, namely with regard to the early modern period. 


\section{FRANCESCO CASSATA}

francesco.cassata@unige.it

Universidade de Genova 